\title{
SULFATE AND GLUCURONIDE CONJUGATES OF BILIRUBIN IN EXPERIMENTAL LIVER INJURY*
}

\author{
By LESLIE J. SCHOENFIELD, JESSE L. BOLLMAN AND HARRY N. HOFFMAN, II
}

(From the Mayo Clinic and Mayo Foundation, Rochester, Minn.)

(Submitted for publication June 1, 1961 ; accepted September 7, 1961)

Free, water-insoluble, indirect-reacting bilirubin is conjugated prior to excretion, predominantly as an ester monoglucuronide and a diglucuronide, forming the water-soluble, direct-reacting pigments $I$ and II, respectively (1-6). The conjugation of bilirubin with glucuronic acid, in the presence of uridine diphosphate glucuronic acid which serves as a glucuronyl donor, is brought about by the enzyme, glucuronyl transferase. It has been shown that conjugated bilirubin also contains nonglucuronide conjugates (7-13).

Isselbacher and McCarthy (12), using $\mathrm{S}^{\mathbf{3 5}}$-labeled sulfate, identified bilirubin sulfate chromatographically and radioautographically in the bile of rats, cats, and humans and in the serum and urine of rats with ligated bile ducts. They observed that the enzymatic biosynthesis of bilirubin sulfate in vitro involves active sulfate and requires adenosine triphosphate. These same authors speculated that the proportions of glucuronide and sulfate conjugates might be altered in certain disease states.

The present study was designed to investigate the relative proportions of glucuronide and sulfate conjugates of bilirubin of laboratory animals after hepatic injury. We also examined the relative proportions of pigments I and II under these same conditions (14).

\section{MATERIALS AND METHODS}

Experimental conditions. Male Wistar rats, weighing 250 to $300 \mathrm{~g}$, were used. Each experimental group contained 6 animals except those groups used for study of bile from the isolated liver, each of which contained 4 animals. To accomplish acute injury, animals were exposed in a closed chamber to vapors of carbon tetrachloride of constant concentration ( $25 \mathrm{mg} \mathrm{CCl}$ per $50 \mathrm{~L}$ air) for 7 hours. Bile fistulas were prepared by cannulating the common bile ducts with polyethylene catheters. The common bile duct was ligated securely with two ties of

* Abridgment of thesis submitted by Dr. Schoenfield to the Faculty of the Graduate School of the University of Minnesota in partial fulfillment of the requirements for the degree of Doctor of Philosophy in Medicine.
4-0 braided silk and the duct was cut between the ties for studies of short (acute) obstruction (24 hours) and of prolonged obstruction (6 to 10 days). In one group acute obstruction was accomplished after exposure to $\mathrm{CCl}_{4}$. This was done to study the added effect of carbon tetrachloride injury on the plasma pigments inasmuch as the exposure alone did not produce jaundiced plasma. Rat liver perfusion preparations (15) were utilized in the study of pigments in bile produced by the isolated liver in response to acute $\mathrm{CCl}_{4}$ injury.

After bile fistulas were prepared in the control groups and in the other groups in which $\mathrm{CCl}_{4}$ was given later, $100 \mu \mathrm{c}$ inorganic radioactive sulfate $\left(\mathrm{S}^{35} \mathrm{O}_{4}\right)$ in normal saline solution was injected intraperitoneally or into the isolated liver system. Bile was then collected for 5 hours on ice and in the dark. For study of the plasma pigments the radioactive-labeled sulfate was administered immediately after obstruction in the acute experiments and 24 hours prior to the time that the animals were killed in chronic-obstruction experiments.

Partition of the pigments. The proteins were precipitated from plasma with saturated $\left(\mathrm{NH}_{4}\right)_{2} \mathrm{SO}_{4}$ and ethanol and from bile with ethanol alone. Siliconized kieselguhr was prepared according to the method of Howard and Martin (16). Reversed-phase partition chromatography of the plasma and bile pigments was carried out by the method of Cole, Lathe and Billing (2), using the butanolphosphate buffer, $\mathrm{pH} 6$, solvent system for separation of the three pigments. The pigment bands were washed from the kieselguhr with $5 \mathrm{ml}$ of diazotized sulfanilic acid and separated by filtration. The relative amounts of pigments I and II were estimated by the 30 -minute direct van den Bergh reaction; the calculations were corrected for volume changes (17). When the diazotized pigments ${ }^{1}$ from columns were dried and placed on paper for chromatography, several compounds were obtained from each, some of which coincided with the radioactivity. In order to purify the products the following procedures taken from Schachter (19) were employed. The azopigments from the columns were evaporated in vacuo at $30^{\circ} \mathrm{C}$ to a volume of $1.5 \mathrm{ml} ; 0.5 \mathrm{ml}$ of $1.5 \mathrm{M}$ glycine buffer, $\mathrm{pH} 2.0$, was added, and the pigments were extracted to $8 \mathrm{ml}$ of butanol saturated with glycine buffer. The azopigments were then placed in $4.5 \mathrm{ml}$ of $2 \mathrm{M}$ acetate buffer, $\mathrm{pH} 3$, and $12 \mathrm{ml}$ of chloroform saturated

1 On diazotization bilirubin is split at the methene bridge so that 1 mole of free bilirubin yields 2 moles of azopigment $A$; 1 mole of pigment $I$ yields 1 mole of azopigment $\mathrm{A}$ and 1 mole of azopigment $\mathrm{B} ; 1$ mole of pigment II yields 2 moles of azopigment B (18). 
with acetate buffer. After shaking and centrifugation, the acetate layer containing azopigment $\mathrm{B}$ was evaporated to dryness. The azopigment $\mathrm{A}$ in the chloroform layer was concentrated by transferring to $4.0 \mathrm{ml} 0.3 \mathrm{~N} \mathrm{NaOH}$ and $16 \mathrm{ml}$ petroleum ether. The $\mathrm{NaOH}$ layer containing azopigment $\mathrm{A}$ was shaken and centrifuged, then taken to dryness. The dried azopigments were dissolved in 50 to $100 \mu 1$ of normal acetic acid in preparation for paper chromatography.

Paper chromatography. Ascending and two-dimensional chromatography on Whatman no. 1 paper was carried out with two different solvent systems: 1) $n$-propionic acid, methyl ethyl ketone, and water (25:75: 30) (12), and 2) pyridine, ethyl acetate, and water (1: $2: 1)(20)$. Ten by 12 -inch sheets were used for the two-dimensional paper chromatography and 1.5 by 22 inch strips for the ascending paper chromatography. Since the amounts of pigment had been estimated after column chromatography, approximately equal quantities of azopigment could be placed on each of the strips. Thus, 50 to $100 \mu \mathrm{l}$ was generally used, depending on the concentration of the pigment. This served as a reference for the estimation of the $\mathrm{S}^{35}$ incorporated as bilirubin sulfate in the various experiments. The chromatographic systems were developed overnight, generally about 16 to 20 hours.

The paper strips were then placed on a chromatogram scanner, and a radioactivity curve was obtained. With the use of a compensating polar planimeter, the amount of radioactivity present on the strips could be estimated by measuring the area under the curve of radioactivity. Preliminary work had demonstrated that the area under both sharply peaked and broad curves, produced by placing known amounts of radioactivity on paper and

TABLE I

Reversed-phase partition chromatography of pigments I and II in bile and plasma of the rat after liver injury

\begin{tabular}{|c|c|c|c|c|}
\hline \multirow[b]{3}{*}{ Experiments } & \multicolumn{4}{|c|}{ Per cent of conjugated pigment* } \\
\hline & \multicolumn{2}{|c|}{ Pigment I } & \multicolumn{2}{|c|}{ Pigment II } \\
\hline & Avg. & Range & Avg. & Range \\
\hline \multicolumn{5}{|l|}{ Bile } \\
\hline $\begin{array}{l}\text { Normal animals } \\
\text { After } \mathrm{CCl}_{4} \text { exposure }\end{array}$ & $\begin{array}{l}14 \\
15\end{array}$ & $\begin{array}{r}9-18 \\
10-20\end{array}$ & $\begin{array}{l}86 \\
85\end{array}$ & $\begin{array}{l}82-91 \\
80-90\end{array}$ \\
\hline \multicolumn{5}{|l|}{ Plasma } \\
\hline $\begin{array}{l}\text { After obstruction of } \\
\text { bile duct for } 24 \\
\text { hours }\end{array}$ & 33 & $29-38$ & 67 & $62-71$ \\
\hline $\begin{array}{l}\text { After } \mathrm{CCl}_{4} \text { exposure; } \\
\text { then obstruction } \\
\text { for } 24 \text { hours }\end{array}$ & 58 & $49-68$ & 42 & $32-51$ \\
\hline $\begin{array}{l}\text { After obstruction of } \\
\text { bile duct for } 6 \text { to } \\
10 \text { days }\end{array}$ & 54 & $48-60$ & 46 & $40-52$ \\
\hline
\end{tabular}

* Six animals in each category.

† Seven-hour exposure to $25 \mathrm{mg} \mathrm{CCl} 4$ per $50 \mathrm{~L}$ air. making radioautographs, was directly proportional to the amount of radioactivity present. The area was calculated for the entire strip and for that portion where radioactivity coincided precisely with the azopigment band. In this manner the bilirubin sulfate could be related to the total amount of sulfate as well as to the total conjugated azopigment in the band.

Radioautographs were made from the sheets on NoScreen X-ray film after a 48-hour exposure and from the strips on Eastman Linagraph ortho film after a 24-hour exposure.

Inasmuch as another unidentified sulfate compound (not bilirubin) was situated on the paper quite near the bilirubin, a perpendicular line was drawn between the two peaks on the curve of radioactivity in order to approximate the area for the bilirubin sulfate. The azopigment bands were cut from the strips precisely, and the pigments were eluted from the paper with $0.05 \mathrm{~N} \mathrm{HCl}$. The optical density at $560 \mathrm{~m} \mu$ was determined in a spectrophotometer and compared with a standard curve prepared with crystalline bilirubin. The eluted pigment was rechromatographed with one or the other solvent system. The radioactivity remained with the pigment band when the chromatogram was scanned and radioautographs were made.

As shown by Isselbacher and McCarthy (12), the eluted, labeled azopigment could not be hydrolyzed by a commercial arysulfatase (Mylase-P). Hydrolysis of bilirubin sulfate could be carried out, however, in normal $\mathrm{HCl}$ at $100^{\circ} \mathrm{C}$ for 90 minutes. The bilirubin glucuronide was hydrolyzed with $50 \mathrm{mg}$ of bacterial $\beta$-glucuronidase at $37^{\circ} \mathrm{C}$ for 24 hours at $\mathrm{pH} 6.2$ with acetate buffer.

Molar ratio of glucuronide to bilirubin in pigment II. This was studied in rats with bile fistulas and in isolated perfused rat livers before and after exposure to $\mathrm{CCl}_{4}$. Simultaneous kieselguhr columns with $1 \mathrm{ml}$ of deproteinized bile were used; one column was for estimation of the bilirubin content of the pigment II band as previously described, the other for the duplicate quantitation of glucuronides in pigment II by the method of Fishman and Green (21). The molar ratio of glucuronide to bilirubin in the pigment II band was calculated.

\section{RESULTS}

Partition of pigments $I$ and II in experimental liver injury. The results of partition and estimation of pigments I and II as obtained from reversed-phase column chromatography of bile or plasma from six animals in each of the various experimental situations are shown in Table I. The pigment patterns in the bile of the normal rat and in the rat after exposure to $\mathrm{CCl}_{4}$ did not differ significantly. When the plasma pigments were studied 24 hours after ligation of the common bile duct, pigment II predominated, but when acute obstruction followed exposure to $\mathrm{CCl}_{4}$ the per- 


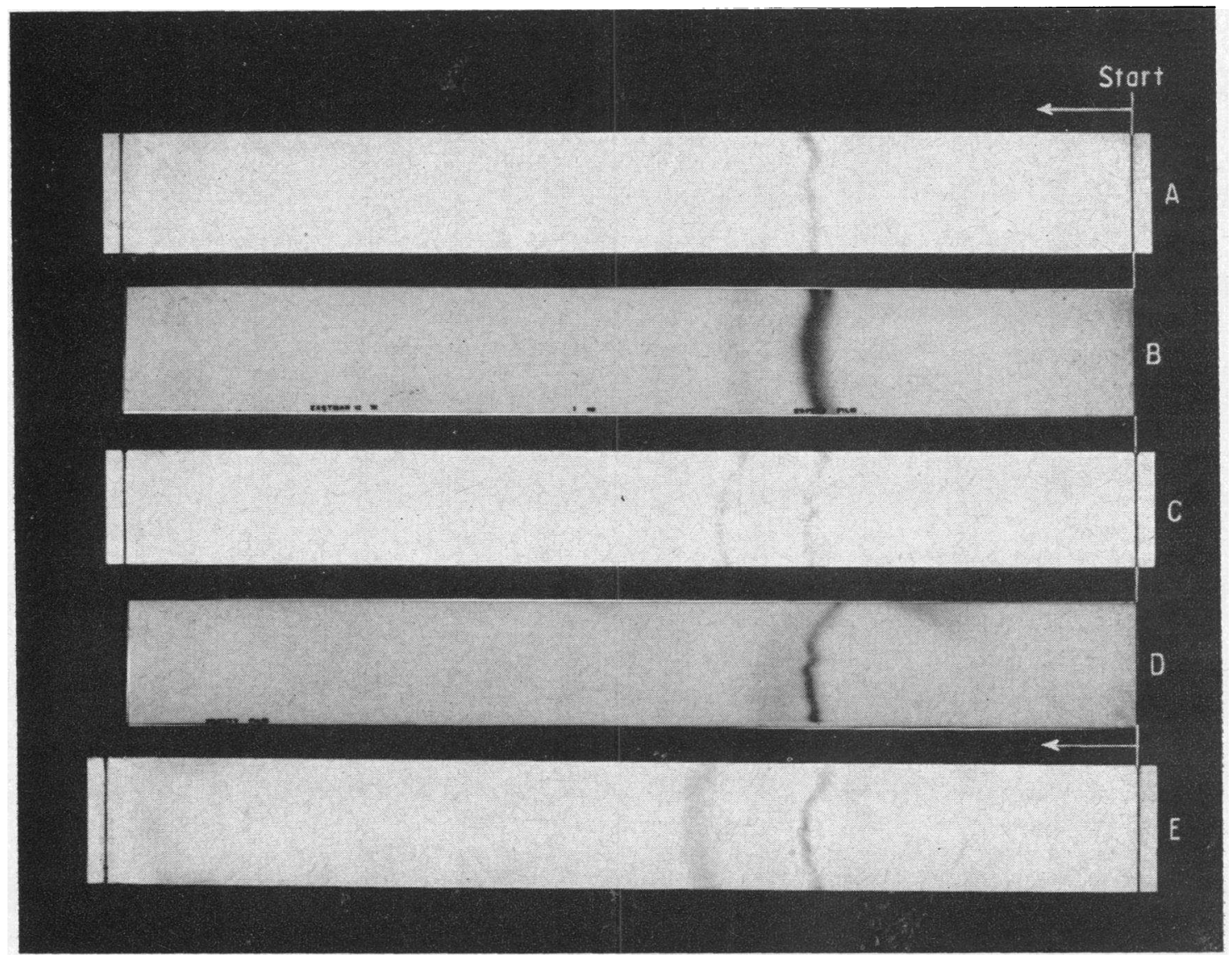

Fig. 1. Chromatographic and Radioautographic Results of $\beta$-gluCURonidase treatment of azopigment CONJUGATED WITH SULFATE AND GLUCURONIDE FROM PIGMENT II OF RAT BILE AFTER EXPOSURE TO 25 Mg OF CARBON TETRACHLORIDE PER $50 \mathrm{~L}$ AIR FOR 7 HOURS AND INJECTION OF $\mathrm{S}^{35} \mathrm{O}_{\star}$. The solvent system used was $n$-propionic acid, methyl ethyl ketone, water $(25: 75: 30)$. A is the unincubated control; $\mathbf{B}$, its radioautograph. C shows the pigments after incubation with bacterial $\beta$-glucuronidase as described in the text; $D$, its radioautograph. It will be noted that a significant portion of the azopigment resists enzymatic hydrolysis and demonstrates radioactivity. By contrast, in normal bile, $\mathbf{E}$, the hydrolyzed azopigment is the more conspicuous.

centage of pigment $\mathrm{I}$ in the plasma increased and usually slightly exceeded that of pigment II. The pigment pattern after prolonged obstruction did not differ from that following combined $\mathrm{CCl}_{4}$ injury and acute obstruction.

Pigment $I$. When the pigment I band from the kieselguhr column was diazotized and purified, two pigments (A and $B$ ) resulted that could be developed on paper chromatography with either of the solvent systems. One pigment band migrated with an $\mathrm{Rf}$ of about 0.5 , which corresponds to diazotized free dipyrrol ; the other migrated with an $\mathrm{Rf}$ of about 0.3 , corresponding to diazotized conjugated dipyrrol. No radioactivity was associated with these azopigment bands from pig- ment I. Rechromatography after elution of the pigments did not alter their rate of movement on the paper. When the conjugated dipyrrol was eluted from the paper chromatograms, incubated with $\beta$-glucuronidase and then rechromatographed, all of the pigment migrated with an $\mathrm{Rf}$ of 0.5 .

Bilirubin sulfate in pigment II of bile and plasma. When the pigment II band from the column was diazotized, purified, and developed on paper chromatography with either of the solvent systems, a single band of azopigment with an Rf of about 0.3 resulted. When this was rechromatographed, eluted from the paper, incubated with $\beta$-glucuronidase, and rechromatographed, two bands of azopigment resulted. One pigment band migrated 
with an $\mathrm{Rf}$ of 0.5 and was not radioactive. The other migrated at an $\mathrm{Rf}$ of 0.3 and was radioactive. When rats had been exposed to $\mathrm{CCl}_{4}$ the azopigment band resistant to enzymatic hydrolysis with $\beta$-glucuronidase was more significant than in normal controls, where the free azopigment band was the more prominent (Figure 1).

The work with two-dimensional chromatograms likewise indicated a relative increase in the amount of bilirubin conjugated with sulfate after exposure to $\mathrm{CCl}_{4}$ as compared with the normal controls (Figure 2).

The results obtained by relating the area of radioactivity associated with the azopigment to the total radioactivity on the strip are shown in Table II. The amount of azopigment was constant in each experiment. After $\mathrm{CCl}_{4}$ injury the percentage of bilirubin sulfate in the total radioactivity increased. An average of 17.8 per cent was found as compared with 12.6 per cent for the controls.
Experiments with isolated liver (Table III) showed a similar increase after $\mathrm{CCl}_{4}$ injury. The correlation of bilirubin- $\mathrm{S}^{35} \mathrm{O}_{4}$ with the amount of nonbilirubin- $\mathrm{S}^{35} \mathrm{O}_{4}$ may be open to question, although the alignment of the calculations in Tables II and III gives credence to the method. It appears that the less $\mathrm{S}^{35} \mathrm{O}_{4}$ available, the less is conjugated with bilirubin. When strips with approximately the same amount of total radioactivity are compared, the differences in $\mathrm{S}^{35}$-bilirubin are significant. Omission of the two high values (normal rats, Table II) leaves all six $\mathrm{CCl}_{4}$-treated rats with higher $\mathrm{S}^{35}$-bilirubin values than have the other four normal rats.

The percentage of bilirubin sulfate in the total radioactive $\mathrm{S}^{35} \mathrm{O}_{4}$ in the plasma after obstruction of the common bile duct is given in Table III. Thus, the same amount of bilirubin in bile from control animals and normal isolated livers and in the plasma after acute obstruction of the common

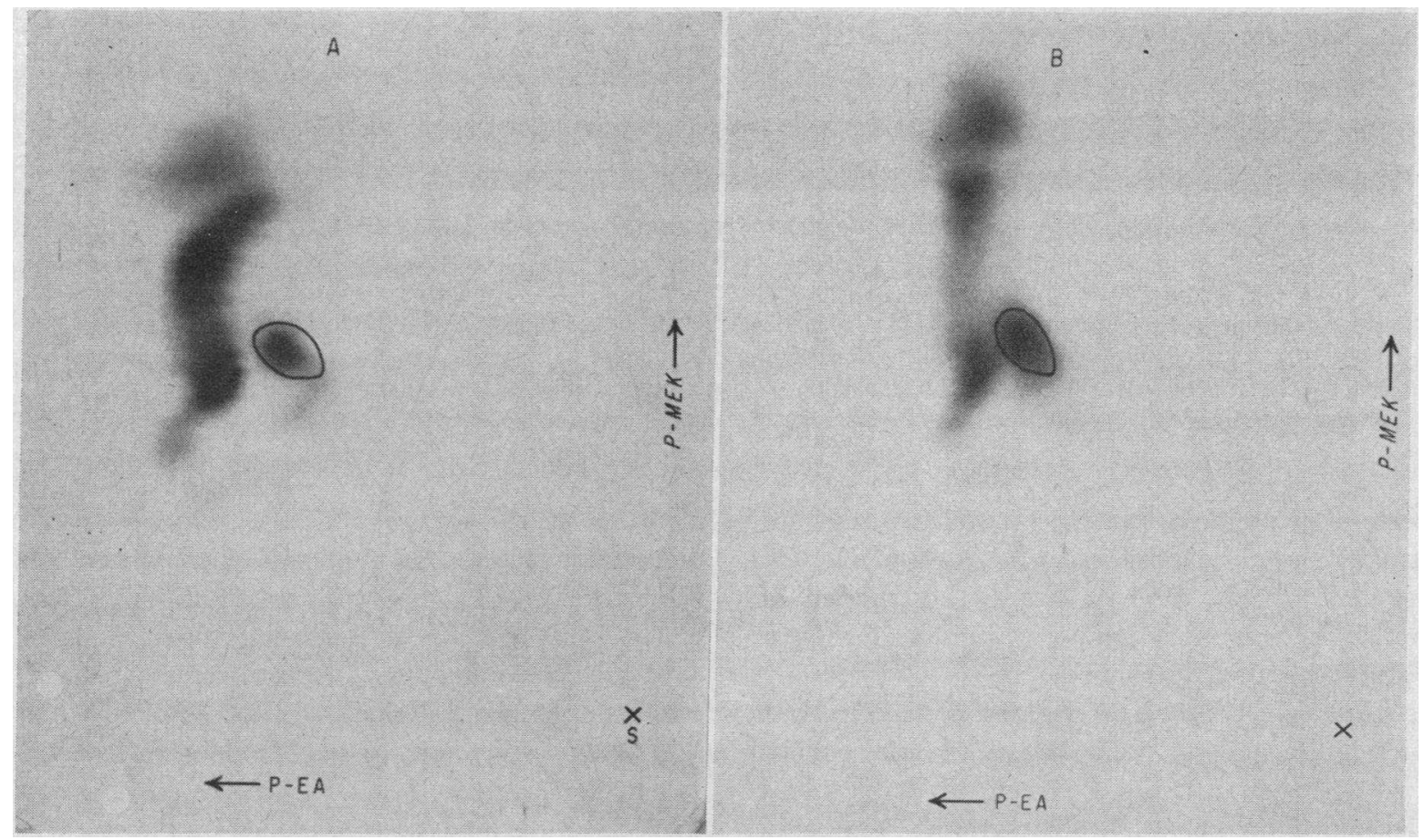

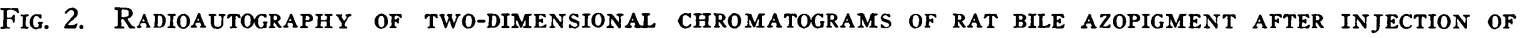
$\mathrm{S}^{25} \mathrm{O}_{4}$. The azopigment was prepared from pigment II as described in the text. The chromatograms have been trimmed to contain the radioactivity and show the start $(X)$ and the directions for the solvent development. The azopigment is outlined on the chromatogram. Both $\mathrm{X}$-ray papers were in contact with the chromatogram for 48 hours. A. This is from the bile of normal rats. B. This is from rat bile after 7-hour exposure to $\mathrm{CCl}_{4}$ vapors $\left(25 \mathrm{mg} \mathrm{CCl}_{4}\right.$ per $50 \mathrm{~L}$ air). Note that with the same amount of azopigment and total radioactivity, there is a greater amount of radioactivity associated with the azopigment after $\mathrm{CCl}_{4}$. 
bile duct is conjugated with an essentially constant percentage of total $\mathrm{S}^{35} \mathrm{O}_{4}$. The corresponding values increased significantly with $\mathrm{CCl}_{4}$ injury and after prolonged obstruction.

Molar ratio of glucuronide to bilirubin. The molar ratio of glucuronide to bilirubin in pigment II obtained from the bile of normal controls averaged 1.74. A decrease in the ratio to 1.17 was

TABLE II

Bilirubin sulfate $\left(\mathrm{S}^{35} \mathrm{O}_{4}\right)$ in pigment II in bile of the rat after exposure to carbon tetrachloride and injection of radioactive sulfate

\begin{tabular}{|c|c|c|c|}
\hline & \multirow{2}{*}{$\begin{array}{c}\text { Area of } \\
\text { total } \\
\text { radio- } \\
\text { active } \\
\text { sulfate } \\
\left(\mathbf{S}^{35} \mathrm{O}_{4}\right) \\
\text { of strip }\end{array}$} & \multicolumn{2}{|c|}{$\underset{\left(\mathrm{S}^{35} \mathrm{O}_{4}\right)}{\text { Bilirubin sulfate }}$} \\
\hline & & Area $†$ & $\begin{array}{l}\text { Total } \\
\text { radio- } \\
\text { activity } \\
\text { in strip }\end{array}$ \\
\hline Normal controls & $\begin{array}{r}s q c m \\
26.1 \\
18.1 \\
38.0 \\
17.4 \\
32.2 \\
24.9\end{array}$ & $\begin{array}{c}s q c m \\
3.2 \\
2.4 \\
4.9 \\
2.2 \\
4.0 \\
3.0\end{array}$ & $\begin{array}{c}\% \\
.12 .3 \\
13.3 \\
12.9 \\
12.6 \\
12.4 \\
12.0\end{array}$ \\
\hline Average & 26.1 & 3.3 & 12.6 \\
\hline After $\mathrm{CCl}_{4}{ }^{*}$ exposure & $\begin{array}{l}22.1 \\
19.6 \\
24.3 \\
18.9 \\
23.2 \\
24.0\end{array}$ & $\begin{array}{l}4.0 \\
3.7 \\
4.2 \\
3.3 \\
4.0 \\
4.3\end{array}$ & $\begin{array}{l}18.1 \\
18.8 \\
17.3 \\
17.5 \\
17.2 \\
17.9\end{array}$ \\
\hline Average & 22.0 & 3.9 & 17.8 \\
\hline
\end{tabular}

* Exposure to $25 \mathrm{mg} \mathrm{CCl}_{4}$ in $50 \mathrm{~L}$ air for 7 hours. The purified azopigment was developed on paper chromatography using $n$-propionic acid, methyl ethyl ketone, and water $(25: 75: 30)$. Each strip contained the same amount of pigment. The strips were placed on a chromatogram scanner and the areas under the curve of radioactivity were measured with a planimeter.

tThe per cent error for repeated measurements of areas of about $20 \mathrm{sq} \mathrm{cm}$ was less than 1 per cent. Smaller areas were brought to at least this dimension by recircumscribing the areas. The figures shown are the averages for three determinations.

found after exposure to $\mathrm{CCl}_{4}$ (Table IV). Similar results were obtained in four experiments using bile from the isolated liver.

\section{COMMENT}

The percentage of pigment $\mathrm{I}$ in bile of the normal rat did not differ from that after $\mathrm{CCl}_{4}$ exposure. This is compatible with the report of Hoffman, Whitcomb, Butt and Bollman who noted that the bile pigment pattern in duodenal drainage of 12 patients with infectious hepatitis did not dif-
TABLE III

Bilirubin sulfate $\left(\mathrm{S}^{35} \mathrm{O}_{4}\right)$ in pigment II in bile and plasma after liver injury and injection of radioactive sulfate; isolated liver preparations and intact animals

\begin{tabular}{|c|c|c|c|}
\hline \multirow[b]{2}{*}{ Experiments } & \multirow{2}{*}{$\begin{array}{l}\text { No. of } \\
\text { animals }\end{array}$} & \multicolumn{2}{|c|}{$\begin{array}{l}\text { Bilirubin sulfate } \\
\left(\mathbf{S}^{850}\right), \text { per cent of } \\
\text { total radioactivits.* }\end{array}$} \\
\hline & & Avg. & Range \\
\hline \multicolumn{4}{|l|}{$\begin{array}{l}\text { Bile, isolated liver } \\
\text { preparation }\end{array}$} \\
\hline Normal animals & 4 & 12.2 & $11.4-13.4$ \\
\hline After $\mathrm{CCl}_{4}$ exposure $\dagger$ & 4 & 17.4 & $17.0-18.6$ \\
\hline \multicolumn{4}{|l|}{ Plasma, intact animal } \\
\hline $\begin{array}{l}\text { After bile duct ob- } \\
\text { struction for } 24 \\
\text { hours }\end{array}$ & 6 & 13.3 & $11.7-13.9$ \\
\hline $\begin{array}{l}\text { After } \mathrm{CCl}_{4} \text { exposuret; } \\
\text { then bile duct ob- } \\
\text { struction for } 24 \\
\text { hours }\end{array}$ & 6 & 19.8 & $19.2-20.4$ \\
\hline $\begin{array}{l}\text { After bile duct ob- } \\
\text { struction, } 6 \text { to } 10 \\
\text { days }\end{array}$ & 6 & 18.5 & $17.4-19.3$ \\
\hline
\end{tabular}

* The purified azopigment was developed on paper chromatography using $n$-propionic acid, methyl ethyl ketone, and water $(25: 75: 30)$. The amount of azopigment was constant in each of the experiments. The per cent bilirubin sulfate of total radioactivity was calculated as indicated in Table II.

† Seven-hour exposure to $25 \mathrm{mg} \mathrm{CCl}_{4}$ in $50 \mathrm{~L}$ air.

fer from normal (14). It may be that the damaged cells are unable to excrete conjugated pigment I into the bile. Two of us (L.J.S. and J.L.B.) and others (22) have identified extrahepatic pigment

TABLE IV

Molar ratio of glucuronide to bilirubin in pigment $I I^{*}$ in bile of the rat after exposure to carbon tetrachloride

\begin{tabular}{|c|c|c|c|c|c|}
\hline \multirow[t]{2}{*}{ Fistula bile } & \multicolumn{2}{|c|}{ Bilirubin } & \multicolumn{2}{|c|}{ Glucuronide } & \multirow[t]{2}{*}{$\begin{array}{l}\text { Molar } \\
\text { ratio, } \\
\text { glucu- } \\
\text { ronide/ } \\
\text { bilirubin }\end{array}$} \\
\hline & $\stackrel{\mathrm{mg} /}{100 \mathrm{ml}}$ & $\begin{array}{c}10^{-7} \\
\text { moles }\end{array}$ & $\stackrel{\mathrm{mg} /}{100 \mathrm{ml}}$ & $\begin{array}{c}10^{-7} \\
\text { moles }\end{array}$ & \\
\hline \multirow[t]{4}{*}{ Normal controls } & 2.4 & 419 & 1.5 & 773 & 1.84 \\
\hline & 2.0 & 349 & 1.2 & 618 & 1.77 \\
\hline & 2.8 & 489 & 1.6 & 824 & 1.69 \\
\hline & 3.2 & 559 & 1.8 & 927 & 1.66 \\
\hline Average & 2.6 & 454 & 1.5 & 786 & 1.74 \\
\hline \multirow[t]{4}{*}{ After $\mathrm{CCl}_{4}$ exposuret } & 3.0 & 524 & 1.2 & 618 & 1.18 \\
\hline & 2.6 & 454 & 1.1 & 567 & 1.25 \\
\hline & 3.2 & 559 & 1.3 & 670 & 1.20 \\
\hline & 3.4 & 594 & 1.2 & 618 & 1.04 \\
\hline Average & 3.6 & 533 & 1.2 & 618 & 1.17 \\
\hline
\end{tabular}

* Pigment II was obtained by reversed-phase partition chromatog raphy using simultaneous columns for the determinations of bilirubin

and glucuronide. 
I and demonstrated its conversion to pigment II by isolated liver of the normal rat. Whether pigment I also is formed in the liver as an intermediate in the production of pigment II is not known. Pigment I has not been found in bile from the isolated rat liver. The significance of this is being studied further.

As Eberlein (23) pointed out, partition methods supply more physiologic information than does the diazotization reaction. However, they do not permit differentiation of primary parenchymal hepatic disease from obstructive jaundice. Study of the pigment patterns in plasma by column chromatography did not provide a means of distinguishing acute $\mathrm{CCl}_{4}$ injury followed by acute obstruction from prolonged obstruction. This probably results from the inevitable secondary parenchymal damage of long-standing biliary obstruction.

No $\mathrm{S}^{35} \mathrm{O}_{4}$-bilirubin was associated with pigment I. All of the conjugated azopigment from pigment I was hydrolyzed by $\beta$-glucuronidase to the free dipyrrol. It is possible, however, that more sensitive methods might reveal a small amount of sulfate or other conjugates of bilirubin in pigment $I$.

It has not been determined whether bilirubin sulfate exists as a monosulfate or disulfate or, indeed, whether a single bilirubin molecule may be conjugated with both sulfate and glucuronic acid. Hydrolysis of azopigment B (containing both sulfate and glucuronide conjugates) by $\beta$-glucuronidase indicated that at least some of the glucuronide exists without sulfate on the same molecule. Animal species differ greatly with regard to the extent of glucuronic acid conjugation and the relative amounts of glucuronide and sulfate conjugates excreted after administration of the same compound (24).

In vitro studies by Chojecki and Kern (25) showed a marked decrease of glucuronyl transferase activity in rat liver homogenates 24 hours after intraperitoneal administration of $\mathrm{CCl}_{4}$. The endoplasmic reticulum, from whence the microsomal fraction of ultracentrifugation is largely derived (26), is apparently the earliest subcellular structure to be pathologically altered in $\mathrm{CCl}_{4}$ poisoning (27). It is likely that similar secondary cytoplasmic organelle damage occurs with prolonged biliary obstruction (28). This probably accounts for the similar results with pigment partitions in the two experimental conditions. Isselbacher and McCarthy (29) observed a quantitative decrease in the liver cell microsomes isolated by ultracentrifugation to account for the decreased hepatic glucuronide-conjugating capacity after intraperitoneally injected $\mathrm{CCl}_{4}$. This decreased activity of glucuronyl transferase is in accord with our in vivo demonstration of a decrease in the molar ratio of glucuronide to bilirubin in pigment II of rat bile after acute exposure to $\mathrm{CCl}_{4}$. These experiments also afford evidence that nonglucuronide conjugation of bilirubin must have been increased. The work with paper chromatography showed that, relative to a constant amount of conjugated bilirubin and to the total output of $\mathrm{S}^{35} \mathrm{O}_{4}$ in the bile, the bilirubin sulfate $\left(\mathrm{S}^{35}\right)$ in pigment II of rat bile increased after exposure to $\mathrm{CCl}_{4}$ for 7 hours and increased equally after prolonged obstruction of the common bile duct. It may be that other nonglucuronide conjugates are increased under these conditions.

Schachter's studies (19), showing a considerably greater renal clearance of the diglucuronide than of the monoglucuronide, suggest that the relative proportions of pigments I and II in plasma may be related to differing renal thresholds for these substances. That the isolated perfused rat liver preparation did form less glucuronide and relatively more sulfate conjugate of bilirubin after exposure to $\mathrm{CCl}_{4}$ indicates that, under these conditions, the differences obviously could not have been functions of the renal thresholds.

\section{SUMMARY AND CONCLUSIONS}

Rats, including those with bile fistulas and isolated perfused liver systems, were utilized for the study of sulfate and glucuronide conjugates of bilirubin. The experimental conditions entailed exposure to carbon tetrachloride and ligation of the common bile duct for short and long periods followed by intraperitoneal injection of inorganic $\mathrm{S}^{35} \mathrm{O}_{4}$. Pigments I and II of bile or plasma were separated and estimated by the technic of reversedphase partition chromatography. The pigments were diazotized, purified further by chemical partition, and placed on paper chromatographic systems for radioautography and analysis.

With acute obstruction to bile flow, pigment II 
was the predominant conjugated pigment in the plasma. With added $\mathrm{CCl}_{4}$ injury or with prolonged biliary obstruction, the proportion of pigment $I$ in the plasma increased.

Sulfate conjugate of bilirubin was not associated with pigment I, but was found with the glucuronide in pigment II. Incubation with $\beta$-glucuronidase permitted the separation of glucuronide from sulfate when chromatographed on paper.

After ligation of the common bile duct for a short period (24 hours), approximately the same proportion of bilirubin sulfate appeared in the pigment II fraction of the jaundiced plasma as is ordinarily present in normal bile. With added $\mathrm{CCl}_{4}$ exposure or after prolonged obstruction, the relative amount of serum bilirubin conjugated as a sulfate increased. Carbon tetrachloride exposure also caused a relative increase in the sulfate conjugate of bilirubin in the bile. This increase was accompanied by a decrease in the proportion of bilirubin conjugated as the diglucuronide. With $\mathrm{CCl}_{4}$ injury a significant decrease in the molar ratio of glucuronide to bilirubin was demonstrated in the bile.

Studies with the isolated perfused rat liver system indicated that formation of bilirubin sulfate depended on an intrahepatic mechanism, although extrahepatic formation was not excluded. In the isolated liver, these altered proportions of sulfate and glucuronide conjugates in response to $\mathrm{CCl}_{4}$ injury are not functions of differing renal thresholds for these substances.

\section{REFERENCES}

1. Cole, P. G., and Lathe, G. H. The separation of serum pigments giving the direct and indirect van den Bergh reaction. J. clin. Path. 1953, 6, 99.

2. Cole, P. G., Lathe, G. H., and Billing, B. H. Separation of bile pigments of serum, bile and urine. Biochem. J. 1954, 57, 514.

3. Billing, B. H., and Lathe, G. H. The excretion of bilirubin as an ester glucuronide, giving the direct van den Bergh reaction (abstract). Biochem. J. 1956, 63, 6P.

4. Talafant, E. Properties and composition of the bile pigment giving a direct diazo reaction. Nature (Lond.) 1956, 178, 312.

5. Schachter, D. Nature of the glucuronide in directreacting bilirubin. Science 1957, 126, 507.

6. Schmid, R., Hammaker, L., and Axelrod, J. The enzymatic formation of bilirubin glucuronide. Arch. Biochem. 1957, 70, 285.
7. Arias, I. M. Recent advances in the metabolism of bilirubin and their clinical implications. Med. Clin. N. Amer. 1960, 44, 607.

8. Jirsa, M., Večerek, B., and Ledvina, M. Di- and mono-taurobilirubin similar to a directly reacting form of bilirubin in serum. Nature (Lond.) 1956, $177,895$.

9. Billing, B. H. Bile pigments in jaundice in Advances in Clinical Chemistry, H. Sobotka and C. P. Stewart, Eds. New York, Academic Press, 1959, vol. 2, pp. 267-299.

10. Billing, B. H., Cole, P. G., and Lathe, G. H. The excretion of bilirubin as a diglucuronide giving the direct van den Bergh reaction. Biochem. J. 1957, 65, 774.

11. Watson, C. J. Color reaction of bilirubin with sulfuric acid: A direct diazo-reacting bilirubin sulfate. Science 1958, 128, 142.

12. Isselbacher, K. J., and McCarthy, E. A. Studies on bilirubin sulfate and other nonglucuronide conjugates of bilirubin. J. clin. Invest. 1959, 38, 645.

13. Boström, H., and Vestermark, A. Ester sulphate pattern of rabbit bile. Nature (Lond.) 1959, 183, 1593.

14. Hoffman, H. N., II, Whitcomb, F. F., Jr., Butt, H. R., and Bollman, J. L. Bile pigments of jaundice. J. clin. Invest. 1960, 39, 132.

15. Brauer, R. W., Pessotti, R. L., and Pizzolato, P. Isolated rat liver preparation: Bile production and other basic properties. Proc. Soc. exp. Biol. (N. Y.) 1951, 78, 174.

16. Howard, G. A., and Martin, A. J. P. The separation of $\mathrm{C}_{12}-\mathrm{C}_{18}$ fatty acids by reversed-phase partition chromatography. Biochem. J. 1950, 46, 532.

17. Malloy, H. T., and Evelyn, K. A. The determination of bilirubin with the photoelectric colorimeter. J. biol. Chem. 1937, 119, 481.

18. Overbeek, J. T. G., Vink, C. L. J., and Deenstra, H. Kinetics of the formation of azobilirubin. Rec. Trav. chim. Pays-Bas 1955, 74, 85.

19. Schachter, D. Estimation of bilirubin mono- and diglucuronide in the plasma and urine of patients with nonhemolytic jaundice. J. Lab. clin. Med. 1959, 53, 557.

20. Schmid, R. The identification of "direct-reacting" bilirubin as bilirubin glucuronide. J. biol. Chem. 1957, 229, 881.

21. Fishman, W. H., and Green, S. Microanalysis of glucuronide glucuronic acid as applied to $\beta$-glucuronidase and glucuronic acid studies. J. biol. Chem. 1955, 215, 527.

22. Schoenfield, L. J., Grindlay, J. H., Foulk, W. T., and Bollman, J. L. Identification of extrahepatic bilirubin monoglucuronide and its conversion to pigment 2 by isolated liver. Proc. Soc. exp. Biol. (N. Y.) 1961, 106, 438.

23. Eberlein, W. R. A simple solvent-partition method for measurement of free and conjugated bilirubin in serum. Pediatrics 1960, 25, 878. 
24. Teague, R. S. The conjugates of D-glucuronic acid of animal origin in Advances in Carbohydrate Chemistry, M. L. Wolfrom, Ed. New York, Academic Press, 1954, vol. 9, pp. 185-246.

25. Chojecki, Z., and Kern, F., Jr. The effect of dietary cirrhosis and $\mathrm{CCl}_{4}$ poisoning on glucuronyl transferase activity of rat liver. Gastroenterology 1961, 40, 521.

26. Palade, G. E., and Siekevitz, P. Liver microsomes: An integrated morphological and biochemical study. J. biophys. biochem. Cytol. 1956, 2, 171.
27. Recknagel, R. O., and Litteria, M. Biochemical changes in carbon tetrachloride fatty liver: Concentration of carbon tetrachloride in liver and blood. Amer. J. Path. 1960, 36, 521.

28. Shaffner, F., and Popper, H. Electron microscopic study of human cholestasis. Proc. Soc. exp. Biol. (N. Y.) 1959, 101, 777.

29. Isselbacher, K. J., and McCarthy, E. A. Effect of carbon tetrachloride upon glucuronide formation by guinea pig liver. Proc. Soc. exp. Biol. (N. Y.) 1960, 103, 819. 